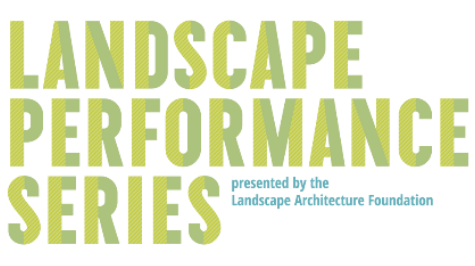

\title{
High Line \\ Methods
}

\section{Case Study Prepared by:}

Research Fellow: Richard Plunz

Professor of Architecture, Columbia University

Research Assistant: Elizabeth Moskalenko, RLA, ISA, LEED Green Associate

MS Civil Engineering Candidate, Columbia University

Firm Liaison: Margaret Jankowsky

Director of Marketing and Business Development, James Corner Field Operations

Agency Liaison: Nicole De Feo, LEED AP+, GRP

Planning and Design Manager, Friends of the High Line

Overview of CSI: This investigation was conducted as part of the Landscape Architecture Foundation's 2017 Case Study Investigation (CSI) program. CSI matches faculty-student research teams with design practitioners to document the benefits of exemplary high-performing landscape projects. Teams develop methods to quantify environmental, economic and social benefits and produce Case Study Briefs for LAF's Landscape Performance Series.

The full case study can be found at: https://landscapeperformance.org/case-study-briefs/high-line

To cite:

Plunz, Richard, and Elizabeth Moskalenko. "High Line Methods." Landscape Performance Series. Landscape Architecture Foundation, 2017. https://doi.org/10.31353/cs1251 


\section{$\underline{\text { Table of Contents }}$}

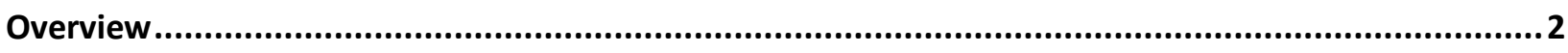

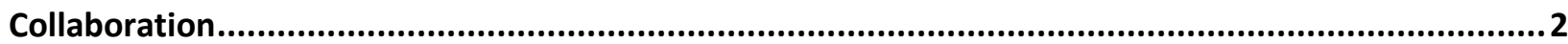

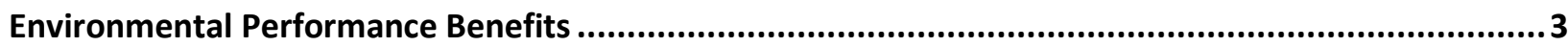

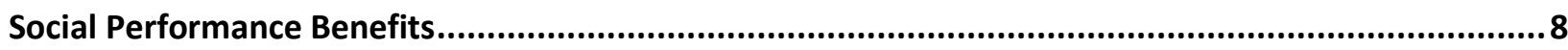

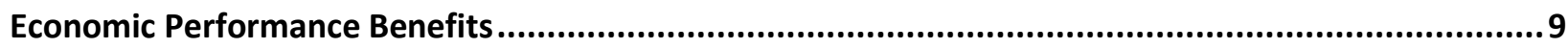

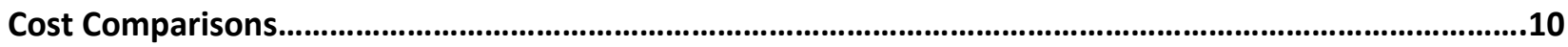

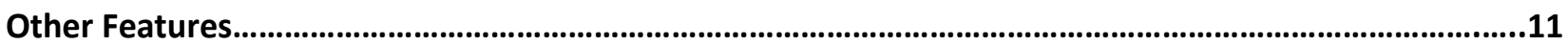

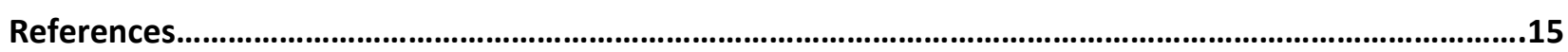

Abbreviations

FHL Friends of the High Line

JCFO James Corner Field Operations

$\mathrm{HL}$ High Line

ISA International Society of Arboriculture

LAF Landscape Architecture Foundation

RLA Registered Landscape Architect

UDL Urban Design Lab 


\section{Overview}

The High Line is a 23-city block-long elevated railway reclaimed as an extraordinary public open space in the heart of Manhattan's West Side and spans three distinct neighborhoods: The Meatpacking District, West Chelsea, and Hell's Kitchen/Clinton.

The original elevated railway was completed in 1934 in response to the inefficient and dangerous conditions on the avenues, with their mix of trains, trucks, and pedestrians. In the 1950s interstate trucking began to replace much of the freight rail system and by 1980 the viaduct was abandoned. In the late 1990s, the High Line was considered a blight on the neighborhood and was under threat of demolition. In 1999 two New Yorkers founded the nonprofit Friends of the High Line in order to save the historic structure and reimagine it as a public park.

The High Line was repurposed in a series of phases: Section 1 (Gansevoort to W. $20^{\text {th }}$ St.); Section 2 (W. $20^{\text {th }}$ to W. $30^{\text {th }}$ St.); Section 3, Phase 1 (W. $30^{\text {th }}$ to W. $34^{\text {th }}$ St.); and Section 3, Phase 2 (along W. $30^{\text {th }}$ St. to the eastern side of $10^{\text {th }}$ Ave.), which opens in 2019. The design is characterized by an intimate choreography of movement, with alternating vistas and experiences along the 1.45-mile length. The High Line's plantings, furnishing, paving, lighting, and utilities were conceived and built as one integrated system within the limited width and depth of the structure itself. Built into this system are a series of 'rooms' which use distinctive planting and speciallydesigned social spaces to emphasize unique site conditions and connect visitors with each other, nature, and the city around them. While the structure is $30 \mathrm{ft}$ high, frequent stairs and elevators provide access and wayfinding from the street level.

Since its opening in 2009, the High Line has become an icon for innovative design, a powerful catalyst for investment, and an inspiration to cities worldwide.

\section{Collaboration}

This case study was successful due to the intense collaboration between Columbia University, James Corner Field Operations, and Friends of the High Line. Both our firm and client liaisons went tremendously beyond the requirements of the program and became part of the research and investigation process as well as engaging their organizations to push the limit of the study.

We wish to offer special thanks to the additional support we received throughout the process to the following individuals whom this extensive project could not have happened without:

From Columbia University: Maria Paola Sutto, Patricia Culligan, Isabel Carrasco, Sriharsha Devulapalli, and Yijia Zhou; James Corner Field Operations: Lisa Switkin, Senior Principal, and Friends of the High Line: Adam Ganser Andi Pettis, Donovan Falls, Brandyn Friedly, Emma Leavens, Kaspar Wittlinger, Tim Kerins, John Gunderson, Erin Eck, Yuki Kaneko, Rachel Hokanson, Maryanne Stubbs, Guilherme Goncalves, Orrin Sheehan, Taryn Cunha, Marek Pundzak, and Nathan Bartholomew. 


\title{
Landscape Performance Indicators
}

\section{Environmental Performance Benefits}

\section{SEQUESTERS OVER 1.3 TONS OF ATMOSPHERIC CARBON ANNUALLY IN 750 NEWLY-PLANTED TREES. THE TREE CANOPIES ALSO INTERCEPT OVER 24,340 GALLONS OF STORMWATER ANNUALLY.}

\author{
Methods: \\ For Tree Survey and i-Tree Eco calibration refer to "Tree Survey," below. \\ Weather station 725053-94729 (NWS Central Park, 2013 data) reported 48.1 inches of total annual \\ precipitation.
}

\section{Tree Survey and Data Modeling:}

The Tree Survey included all woody species in the tree community (trees and shrubs) that were 1" or larger in caliper. The survey was conducted over seven visits, on June 22, 23, 24, 26, 27, 29, and July 3, 2017, by Elizabeth Moskalenko, ISA Certified Arborist. 750 woody plants were surveyed with 47 different species accounted for.

The survey data was compared with original planting plans and schedules, along with notes from FHL gardeners to check proper species. Where discrepancies existed, the survey data collected were used. A $10 \%$ error should be assumed for the survey data. Furthermore, due to the general size of trees and the base of the crown height, many trees were surveyed lower than typical DBH heights (4.5'). If the tree was single stem and crown started low (i.e. 1') it was measured below the crown. Therefore, caliper and DBH were used interchangeably situationally dependent. It should be noted that $\mathrm{DBH} /$ caliper are measured by estimation.

I-Tree Eco version 6 was used to model ecosystem services and structural characteristics. The program provides estimates of the urban forest structure, pollution reduction, public health impacts, carbon storage and sequestration, energy savings, avoided stormwater runoff, tree growth forecasts including health and pest impacts, bioemissions, compensatory and economic value, and potential pest impacts. iTree is an adaptation of the Urban Forest Effect (UFORE) model developed by the US Forest Service Northern Research Station, United States Department of Agriculture State and Private Forestry's Urban and Community Forestry Program and Northeastern Area, Davey Tree Expert Company, and SUNY College of Environmental Science and Forestry. For more information on the modeling software, along with its most recent updates, parameters, and limitations refer to the i-Tree website page "i-Tree Eco" at https://www.itreetools.org/eco/.

\section{Limitations:}

Due to program constraints, information such as multi-stem or single stem was not used. Therefore, the numbers and data are actually underrepresented as one tree may have five stems with calipers or 3-7". The largest caliper of one stem was used in the model.

The phrase "more than" is consistently used throughout this document because tree survey and modeling does not take into account trees and other woody species less than 1" in caliper, account for the difference in volume in multi-stem trees, nor consider other vegetation. This underestimates the site's contribution due to certain factors not provided in the model.

For additional limitations of the modeling software, refer to www.itreetools.org/eco. 


\section{INCREASED PLANT SPECIES DIVERSITY BY OVER 200\% FROM 245 SPECIES AND CULTIVARS TO 500 SPECIES AND CULTIVARS. ACHIEVES A SIGNIFICANT LEVEL OF SPECIES RICHNESS WITH 47 WOODY SPECIES AND A SIMPSON RECIPROCAL INDEX (SRI) VALUE OF 15.14, AS COMPARED TO MADISON SQUARE PARK, A SIMILARLY-SIZED PARK WITH 29 WOODY SPECIES AND AN SRI OF 12.10.}

\section{Note \& Speculation:}

This comparison depicts plant species biodiversity pre- and post-redevelopment of the structure. If the HL structure had been demolished and removed, it would have been replaced with building infill. While this is not directly quantifiable, the elevated plantings on the $\mathrm{HL}$ inspired surrounding development to include vegetation as well. Overall, vegetation in the footprint of the HL would not likely exist unless in the form of an intensive or extensive green roof.

\section{Methods:}

Three vegetation surveys were conducted before and while the HL was in design and development. The first, "The flora on the High Line, New York City, New York" in 2004, the second, "The High Line, Phase 1 Ecological Assessment Report" in 2004, and the third, "Railyards Plant Survey," 2011. The vascular vegetation from these three lists were combined to represent the post-industrial use and preredevelopment plant palette of the $\mathrm{HL}$. This combined list was compared with the current species list maintained and updated in Cartegraph (a GIS-based software) by the FHL Horticulture Department.

Biological diversity was measured for the trees and other woody species 1" in caliper or greater. Tree survey of the High Line was conducted by Elizabeth Moskalenko, ISA Certified Arborist, in June and July of 2017. See "Tree Survey" for further information. This list was compared to species list developed by FHL gardeners using Cartegraph. Where discrepancies existed between the two, the survey list was reevaluated.

A survey of trees in Madison Square Park was completed by Elizabeth Moskalenko on August 21, 2017. Only woodies over 1 " in caliper were accounted for. The list of trees and large shrubs has slight variance to that found on the Madison Square Park website, and survey list should be evaluated as an estimate only, with a $15 \%$ assumed error. The park is 7.43 acres in size with 214 woody plants with trunks over 1" in caliper accounted for.

The Simpson Reciprocal Index (SRI) was used to measure woody diversity on the HL, specifically, for the tree community. The two main factors that the SRI uses to quantify diversity are species richness and evenness. Richness is the number of different organisms present, while evenness is the relative abundance of the species present. Diversity increases as species richness and evenness increases. The lower limitation of the SRI is 1 , as this would represent a community of only 1 species. The higher the number, the greater the diversity. The maximum value would be the number of species in the sample. This maximum number would only be reached if the distribution of the population of all species were basically even. ("Simpson's Diversity Index").

$$
D=\frac{1}{\left(\frac{\sum n_{i}\left(n_{i}-1\right)}{N(N-1)}\right)}
$$

Key: 
$D=$ Diversity; $n_{i}=$ population of an individual species; $N=$ Total number of individuals

$$
15.14=\frac{1}{\frac{37,106}{750(750-1)}}
$$




\begin{tabular}{|c|c|c|c|}
\hline & Totals: (47 species) & 750 & 37,106 \\
\hline Scientific Name & Common Name & $\mathrm{n}$ (Number of Trees) & $n(n-1)$ \\
\hline Betula populifolia & Gray birch & 131 & 17,030 \\
\hline Amelanchier laevis & Smooth service berry & 63 & 3,906 \\
\hline Rhus typhina & Staghorn sumac & 63 & 3,906 \\
\hline Sassafras albidum & Sassafras & 60 & 3,540 \\
\hline Juniperus virginiana & Eastern red cedar & 50 & 2,450 \\
\hline Magnolia macrophylla & Bigleaf magnolia & 35 & 1,190 \\
\hline Populus tremuloides & Quaking aspen & 34 & 1,122 \\
\hline Amelanchier arborea & Downy serviceberry & 25 & 600 \\
\hline Rhus glabra & Smooth sumac & 24 & 552 \\
\hline Prunus virginiana & Common chokecherry & 20 & 380 \\
\hline Cercis canadensis & Eastern redbud & 19 & 342 \\
\hline Aescelus parviflora & Bottlebrush buckeye & 18 & 306 \\
\hline Prunus serotina & Black cherry & 18 & 306 \\
\hline Populus grandidentata & Bigtooth aspen & 17 & 272 \\
\hline Magnolia virginiana & Sweetbay magnolia & 15 & 210 \\
\hline Acer triflorum & Three-flower maple & 12 & 132 \\
\hline Carpinus betulus & European hornbeam & 12 & 132 \\
\hline Cornus sanquinea 'Midwinter Fire' & Bloodtwig dogwood & 12 & 132 \\
\hline Ilex ораса & American holly & 10 & 90 \\
\hline Nyssa sy/vatica & Black tupelo & 9 & 72 \\
\hline Amorpha fruticosa & Desert false indigo & 8 & 56 \\
\hline Magnolia tripetala & Umbrella magnolia & 8 & 56 \\
\hline Malus floribunda & Japanese flower crabapple & 7 & 42 \\
\hline Cotinus spp. & Smoketree spp. & 7 & 42 \\
\hline Carpinus caroliniana & American hornbeam & 6 & 30 \\
\hline Cornus spp. & Dogwood spp. & 6 & 30 \\
\hline Ptelea trifoliata & Common hoptree & 6 & 30 \\
\hline Quercus macrocarpa & Bur oak & 6 & 30 \\
\hline Cotinus coggygria & Smoke tree & 5 & 20 \\
\hline Gymnocladus dioicus & Kentucky coffeetree & 5 & 20 \\
\hline Hamamelis $x$ intermedia 'Jelena' & Jelena Witchhazel & 5 & 20 \\
\hline Rhus copalinum & Shining sumac & 5 & 20 \\
\hline Populus deltoides & Eastern cottonwood & 4 & 12 \\
\hline Cotinus ovatus & American smoketree & 3 & 6 \\
\hline Salix elaeagnos & Eleagnus willow & 3 & 6 \\
\hline Clerodendrum trichotomum & Harlequin glorybower & 3 & 6 \\
\hline Chionanthus retusus & Chinese fringe tree & 2 & 2 \\
\hline Cornus alternifolia & Pagoda dogwood & 2 & 2 \\
\hline Malus sargentii & Sargent's apple & 2 & 2 \\
\hline Pyrus calleryana & Callery pear & 2 & 2 \\
\hline Chaenomeles speciosa 'Toyo-Nishiki' & Japanese quince & 2 & 2 \\
\hline Styrax japonicus 'Sohuksan' & Japanese snowbell & 1 & 0 \\
\hline Chionanthus spp. & Fringe tree & 1 & 0 \\
\hline Malus spp. & Apple spp. & 1 & 0 \\
\hline Salix spp. & Willow spp. & 1 & 0 \\
\hline Salix chaenomeloides & Giant pussy willow & 1 & 0 \\
\hline Salix gracilistyla melanostachys & Black pussy willow & 1 & 0 \\
\hline
\end{tabular}

Figure 1- High Line Tree Community Habitat Biodiversity 


\begin{tabular}{|c|c|c|c|}
\hline & Totals: (29 species) & 214 & 3,768 \\
\hline Scientific Name & Common Name & $\mathrm{n}$ (Number of Trees) & $n(n-1)$ \\
\hline Platanus $x$ acerifolia & London planetree & 44 & 1,892 \\
\hline Quercus palustris & Pin oak & 25 & 600 \\
\hline Ginkgo biloba & Ginkgo & 20 & 380 \\
\hline Prunus $x$ cisterna & Purple-leaf sandcherry & 15 & 210 \\
\hline llex opaca & American holly & 13 & 156 \\
\hline Hibiscus syriacus & Common hibiscus & 12 & 132 \\
\hline Ulmus spp. & Elm & 10 & 90 \\
\hline Cornus mas & Cornelian cherry & 9 & 72 \\
\hline Prunus serrulata 'Kwanzan' & Kawnzan cherry & 8 & 56 \\
\hline Crataegus spp. & Hawthorn & 7 & 42 \\
\hline Malus spp. & Crabapple & 7 & 42 \\
\hline Cercis canadensis & Eastern redbud & 5 & 20 \\
\hline Robinia psuedoacacia & Black locust & 5 & 20 \\
\hline Cornus alternifolia & Pagoda dogwood & 4 & 12 \\
\hline Gymnocladus dioicus & Kentucky coffeetree & 4 & 12 \\
\hline Fraxiunus americana & White ash & 3 & 6 \\
\hline Lagerstroemia spp. & Crapemyrtle & 3 & 6 \\
\hline Quercus bicolor & Swamp white oak & 3 & 6 \\
\hline Stewartia pseudocamellia & Japanese stewartia & 3 & 6 \\
\hline Aesculus carnea & Red horse-chestnut & 2 & 2 \\
\hline Cladrastis kentukea & Yellowwood & 2 & 2 \\
\hline Cotinus spp. & Smoketree & 2 & 2 \\
\hline Hamemelis spp. & Witchhazel spp. & 2 & 2 \\
\hline Cercidiphyllum japonicum & Katsura tree & 1 & 0 \\
\hline Celtis occidentalis & Common hackberry & 1 & 0 \\
\hline Magnolia spp. & Magnolia & 1 & 0 \\
\hline Pinus spp. & Pine & 1 & 0 \\
\hline Styrax japonicus & Japanese snowbell & 1 & 0 \\
\hline
\end{tabular}

Figure 2 - Madison Square Park Tree Community Habitat Biodiversity

\section{Limitations:}

Biological diversity was only measured for the trees and other woody species 1 " in caliper or greater. Data was not compared for woody plants less than 1" in caliper, herbaceous species, or to predevelopment conditions, as this data is not available.

\section{RECYCLES 100\% OF WASTE PLANT MATERIALS ON-SITE, GENERATING 90 CU YDS OF COMPOST IN 2016.}

Source:

$90 \mathrm{cu}$ yds of compost was created in 2016 from plant debris. This number is estimated from the FHL horticultural department, with a 10\% margin for error. This will increase as FHL recently acquired a 1,750 LI capacity Rocket A900 Composter. Numbers reported by FHL. As of 2016, all cutback debris - and all other plant material collected throughout the year - is composted on-site. In 2016, this included 3,645 cubic feet of plant debris from cutback alone. 


\section{Social Performance Benefits}

1. ATTRACTED 7.6 MILLION VISITORS IN 2015, MORE VISITORS THAN 10 OTHER MAJOR NEW YORK CITY LANDMARKS INCLUDING THE METROPOLITAN MUSEUM OF ART. MORE THAN 31\% OF 2015 VISITORS WERE FROM NEW YORK CITY, 6\% OF WHICH WERE FROM THE HIGH LINE'S SURROUNDING NEIGHBORHOOD.

Method:

FHL gathered 2015 data by counting the park's daily visitors and predicted visitation based on long-term patterns. Visitors were tracked by staff members who performed counts at one-hour intervals in eight different zones of the park. This data was then entered into an algorithm to estimate total visitors which take into account the average length of visit, day of the week, time of day, weather, and number of visitors along each section. Further information can be found in the article "Big Data and Parks." Data obtained from the article, "Visualizing Visitor Data," which aggregates visitor survey data and studies. In 2015, the following visitorship was calculated at each landmark: High Line 7.6 M, Metropolitan Museum of Art 6.3 M, Empire State Building 4.2 M, State of Liberty 4.3 M, Museum of Modern Art 3.0 M, Guggenheim 1.2 M, Whitney Museum 1.0 M, New York Botanical Garden 0.9 M, Brooklyn Botanic Garden $0.8 \mathrm{M}$, New Museum .4 M, and Brooklyn Bridge Park 0.2 M. Family and event programming determined by FHL data review of programs and visitorship.

FHL has conducted comprehensive visitor surveys to gauge usership background and experiences since 2009. Visitors in 2015 from NYC were $6 \% \mathrm{HL}$ area, 11\% Manhattan outside $\mathrm{HL}$ area, and $13 \%$ other boroughs; and Non-NYC residents were $30 \%$ outside NYC (outside 45 miles), 28\% outside the US, 5\% outside NYC (within 45 miles), and $4 \%$ outside NYC (within 15 miles).

2. HOSTS MORE THAN 26,000 PEOPLE ANNUALLY FOR PROGRAMMED EVENTS, WITH NEW YORK CITY RESIDENTS REPRESENTING AT LEAST 75\% OF EVENT ATTENDEES.

Source:

FHL data review of programs and visitorship.

3. EDUCATES MORE THAN 12,000 CHILDREN ANNUALLY THROUGH MORE THAN 400 EDUCATIONAL SESSIONS. AN ADDITIONAL 2,500 VISITORS PARTICIPATED IN OVER 130 FREE PUBLIC TOURS IN 2016.

Source:

FHL data review of programs and visitorship. Children's tours focus on the park's history, design, horticulture, and public art. 138 free public tours were offered on the HL in 2016.

4. PROMOTES AWARENESS OF LANDSCAPE ARCHITECTURE THROUGH SOCIAL MEDIA AND PUBLICATIONS, WITH MORE THAN 5 MILLION WEBSITE VIEWS AND A SIGNIFCANT SOCIAL MEDIA FOLLOWING, AND BEING FEATURED IN MORE THAN 500 ARTICLES PER YEAR.

Source:

FHL analyses of social media data. The HL has 182,421 Facebook followers and 142,000 Instagram followers as of August 2017 and 5,126,915 website page views in 2016 alone. The HL is mentioned in thousands of press stories every year, including travel stories about New York, other cities attempting to develop their own infrastructure reuse projects, in those regarding urban gardening and the 
importance of green space in cities, and on how spaces similar to the HL is changing the city dynamic. At minimum, the $\mathrm{HL}$ is prominently featured in $\mathbf{5 0 0}$ stories each year. Information was gathered by FHL.

Examples of recent press on the High Line include:

http://www.pbs.org/program/ten-that-changed-america/10-parks-changed-america/

http://www.wnyc.org/story/highline/

https://www.mnn.com/your-home/organic-farming-gardening/stories/a-gardeners-guide-New-York-

high-line

http://chelseanow.com/2016/09/little-prairie-on-the-high-line/

http://www.gardencentermag.com/article/elevating-public-gardens/

Limitations:

Not all stories are tracked by FHL.

5. PROMOTES HEALTH AND WELL-BEING FOR MORE THAN 1,150 PEOPLE ANNUALLY THROUGH FREE PUBLIC PROGRAMMING ON MEDITATION, TAI CHI, AND STARGAZING.

Method:

FHL maintains records of programming and events. In 2016 there were 26 sessions of Meditation and Tai Chi with 570 total participants. There were also 29 stargazing session events with a minimum of 580 total attendees. The total of health and well-being participants is over 1,150.

6. ATTRACTS MORE DIVERSE VISITORS EACH YEAR, WITH $34 \%$ OF SURVEYED VISITORS IDENTIFYING AS NON-WHITE IN 2015 AS COMPARED TO 19\% IN 2010. 44\% OF SURVEYED NEW YORK CITY RESIDENT VISITORS IDENTIFIED AS NON-WHITE IN 2015.

Method:

FHL has conducted comprehensive visitor surveys to gauge usership background and experiences since 2009. The surveys include ethnicity and point of origin, activities participated in during visit, and user recommendations. 44\% of New York City residents identified as non-white in 2015 as compared to 24\% in 2009-2010. ("Big Data and Parks," 2016).

\section{Economic Performance Benefits}

1. GENERATES TAX REVENUE. THE HIGH LINE WILL HAVE GENERATED OVER \$1.4B IN TAX REVENUE FOR NEW YORK CITY BETWEEN 2007 AND 2027, ROUGHLY \$65M ANNUALLY.

2. CATALYZED OVER \$2 BILLION IN NEW DEVELOPMENT. SINCE 2007, THERE ARE 3,000 NET NEW DWELLING UNITS IN WEST CHELSEA. AS OF 2018, 700 OF THESE NEW UNITS ARE RENT REGULATED THROUGH THE 421A/AFFORDABLE NEW YORK PROGRAM. AN ESTIMATED ADDITIONAL 300 EXISTING UNITS IN WEST CHELSEA HAVE BECOME RENT REGULATED THROUGH PROGRAMS SUCH AS THE J-51 TAX ABATEMENT. 
Source:

Data gathered from 2002 HR\&A study and The High Line: Economic Impact Assessment, HR\&A, March 2015, updated 2018.

\section{Cost Comparisons}

1. DEMOLITION AND REMOVAL OF THE STRUCTURE WAS ESTIMATED TO COST \$27 MILLION. HOWEVER, REMOVAL OF THE HIGH LINE'S STRUCTURE WOULD HAVE NEGATED THE CITY'S PRIOR INVESTMENT IN ITS ORIGINAL USE AS A TRANSPORTATION PROJECT THAT COST THE CITY \$125 MILLION IN 1930, THE EQUIVALENT OF \$1 BILLION IN 2002.

\section{Method:}

Demolition costs of the High Line was covered in the HR\&A report with estimates completed by Handscomb, Inc. to conduct estimates for the potential demotion, long-term stabilization, redevelopment and operational costs of the High Line. Handscomb estimated that it would costs \$27 million to demolish the HL which includes construction costs for demolishing the structure, allowance for repairs to approximately ten properties damaged because of demolition, the costs of temporary protection of maintenance and traffic and shoring during construction. This estimate also includes all hard and soft costs and gives a significantly contingency to account for the uncertainties associated with demolition (HR\&A, 2002).

2. REPURPOSING THE HIGH LINE WAS PREDICTED TO PROVIDE TAX REVENUE TO THE CITY OF NEW YORK EQUAL TO 200-300\% OF THE ESTIMATED CAPITAL COSTS OF \$65 MILLION. AS OF 2018, WHILE THE CITY'S INVESTMENT IN THE HIGH LINE IS CLOSER TO \$140 MILLION, THE INCREMENTAL TAX REVENUE FOR THE CITY IS CLOSER TO \$1.4 BILLION, MORE THAN 900\% OF THE CAPITAL COSTS.

Method:

The City of New York requested FHL assess the feasibility of the construction of public open space on the HL. The study assessed the constructability of the park given current federal and municipal regulatory requirements and calculated the balance between cost of construction and incremental revenue to the city generated by the $\mathrm{HL}$. The study was completed in 2002 , predicting construction cost and revenue returns. The report concluded that the $\mathrm{HL}$ would provide tax revenue to the city greater than the cost of re-purposing the structure. The cost of construction was estimated to be $\$ 65$ million. $\$ 65$ million was the midpoint between two cost estimates which differed on the amount of concrete that needed to be replaced and the level of finish that would be needed, while also accounting for contingencies. The HR\&A report provides a range of estimates with a mid-range of real estate tax revenues and with an assumption that the city assumes no more than half the cost of construction, a conservative assumption of revenue was $200-300 \%$ of the total construction costs. FHL and HR\&A revisited these prediction $\sin 2018$. With much of the High Line completed, the total capital costs of the High Line are closer to $\$ 200$ million. The City of New York invested $\$ 140$ million and the projected tax revenue through 2027 has a net present value in 2018 \$1.4 billion (HR\&A, 2002, 2018). 


\section{Other Features}

1. REMEDIATED THE SITE'S BROWNFIELD CONDITION AND ESTABLISHED A SOIL DEPTH OF 18 TO 24 IN, AROUND 9,300 CU YDS OF HEALTHY SOIL, ACROSS 47\% OF THE PARK.

\section{Methods:}

According to the EPA (www.epa.gov) the term brownfield can refer to the reuse of a property which may be complicated by the presence, or potential presence of a hazardous substance, pollutant, or contaminant. Soil formed on the High Line $(\mathrm{HL})$ was exposed to almost 50 years of diesel rail traffic. Environmental studies were conducted pre-reconstruction to determine levels of contamination.

Contamination of the High Line in 2006 included the following: Asbestos on track bed, railroad ties and plates, discarded solid waste, and structural steel components covered with lead-based paint. Soil samples tested positive for unknown diesel range organics and low levels of cyanide. The compounds with highest concentrations found in the soil were polycyclic aromatic hydrocarbons (PAH) and metals. The metals which exceeded the New York State Department of Environmental Conservation Technical Assistance Guidance Memorandum included arsenic, copper, chromium, zinc, and mercury. Refer to both reports by GRB, 2006, for further information.

To remediate the $\mathrm{HL}$, this contaminated soil was removed and replaced with engineered soil. All asbestos and solid waste was removed, and lead, heavy metals, and creosote was abated.

Engineered soil was installed on the $\mathrm{HL}$ during construction of the park. Soil tests were conducted by the University of Massachusetts Soil and Plant Nutrient Testing Laboratory on July 19, 2016. The lab uses the Modified Morgan extraction which is a universal extraction procedure that determines all major nutrients and micronutrients simultaneously. Soil health is an assessment of how well a soil performs all of its functions and is evaluated though indicators (Spargo et al, 2013). A summary of soil test results reported on July 19,2016 , from a sample on the $\mathrm{HL}$ is provided in the chart below. 


\begin{tabular}{|l|c|c|}
\hline \multicolumn{3}{|c|}{ Soil Health Assessment Results } \\
\hline Indicator Analysis & Value Found & Optimum Range \\
\hline Soil pH (1:1, H20) & 5.8 & \\
\hline Phosphorus (P) & 16.0 & $4-14$ \\
\hline Potassium (K) & 24.0 & $100-160$ \\
\hline Calcium (Ca) & 1268.0 & $1000-1500$ \\
\hline Magnesium (Mg) & 164.0 & $50-120$ \\
\hline Sulfur (S) & 12.9 & $>10$ \\
\hline Boron (B) & 0.2 & $0.1-0.5$ \\
\hline Manganese (Mn) & 1.3 & $1.1-6.3$ \\
\hline Zinc (Zn) & 3.5 & $1.0-7.6$ \\
\hline Copper (Cu) & 0.3 & $0.3-0.6$ \\
\hline Iron (Fe) & 3.6 & $2.7-9.4$ \\
\hline Aluminum (Al) & 10.0 & $<75$ \\
\hline Lead (Pb) & 1.0 & $<22$ \\
\hline Cation Exchange Capacity, meq/100g & 11.5 & \\
\hline Exchange Acidity, meq/100g & 3.8 & \\
\hline Calcium Base Saturation & 55.0 & $50-80$ \\
\hline Magnesium Base Saturation & 12.0 & $10-30$ \\
\hline Potassium Base Saturation & 1.0 & $2.0-7.0$ \\
\hline Scoop Density, g/cc & 1.1 & \\
\hline Soil Organic Matter (LOI), \% & 4.7 & \\
\hline Nitrate-N (NO3-N), ppm & 26.0 & \\
\hline *Micronutrient defiencies rarely occur in New England soils; therefore, an Optimum \\
Range never been defined. Values provided represent the normal range found in soils \\
and are for reference only. (Source: UMassExtension Soil Test Report, July 19, 2016) \\
\hline
\end{tabular}

Total project area designed for Sections 1, 2, and 3 is 256,141 sf. The area values were taken from "The High Line: Seen Unforeseen." Soil depth on the HL ranges from 8-36 in. Volume of soil, 9,306 cu yds, is given in the article "A Skyscraper on its Side."

\section{Limitations:}

Comparisons of soil volumes from pre-park development were difficult to determine as there is a range of soil depths that developed from windblown dust and dead plant material from $0.03-2.3 \mathrm{ft}$ (Statler, 2005 and Ecological Assessment Report, 2004). These two numbers averaged across the area of the HL would have yielded vastly different amounts.

2. CREATES 125,640 SF OF CULTIVATED GARDENS IN MANHATTAN, 110,000 PERENNIALS AND GRASSES, WITH OVER 30\% OF VEGETATION ATTRACTING POLLINATOR SPECIES, IN ADDITION TO OTHER SPECIES FROM DIFFERENT REGIONS PERFORMING THE SAME ECOSYSTEM SERVICES.

\section{Methods:}

Data was gathered through use of FHL maintained garden records and "A Skyscraper on its Side" article. This measurement does not include the Rail Yards.

The HL is in the region designated 221 in the Baileys' Ecosystem Provinces: The Eastern Broadleaf Forest, Oceanic Province. A species list of the HL was compared with the guide list on selecting plants for pollinators in this region distributed by the Pollinator Partnership and NAPPC (Ley, ND). Species which were similar (same genus) as listed in resource were marked as pollinator species. Bulbs and species in the Rail Yards were not included in the analysis. Over 30\% of species, 115 out of 378, were marked as pollinator plant species according to this chart. 35 out of 66 species listed in the chart were found on the HL. 


\section{Limitations:}

This resource list should not be considered exhaustive, as there are many more plants that are well suited for pollinators, either as forage or habitat, along with those that may not be commonly found in this region. Regional pollinator lists do not consider plants from outside of the region, which can also serve as a food source and habitat. Furthermore, the HL planting design is optimized to provide food for pollinators throughout the seasons, offering a variety of plants with overlapping and sequential bloom periods.

\section{REDUCES THE PARK'S ANNUAL ENERGY CONSUMPTION BY PROVIDING LED FIXTURES FOR 79\% OF LIGHTING.}

Method:

Lighting information was provided by the FHL Operations team. Light fixtures are divided between LED $-2,562$ (79\%), Fluorescent - 391 (12\%), and Metal Halide - 297 (9\%). The primary areas of the fluorescent lighting are in the $14^{\text {th }}$ Street Passage (71 fixtures), the Chelsea Market Passage (238), and park undersides near staircases. The metal halide fixtures are primarily located on the underside of the $\mathrm{HL}$ at street crossovers, as required by the NYC Department of Transportation and at the tree uplights.

\section{REDUCES SOLAR REFLECTANCE BY PROVIDING OVER 3.5 ACRES OF GREEN ROOF.}

Method:

Due to the site's industrial history, there is a significant lack of public open spaces and vegetated areas in the area. Far West Chelsea functioned as a manufacturing area. Hudson River Park has become an amenity on the western edge of the neighborhood, but it is already a heavily used park, highlighting the need for additional public open spaces (HR\&A, 2002). The High Line provides 7.43 acres of public open green space that would not exist otherwise unless purchased later by the city or state, with over $60 \%$ of this vegetated space.

\section{ALL 1.45 MILES OF THE PARK ARE UNIVERSALLY ACCESSIBLE, INCLUDING ALL PARK FEATURES.}

Method:

Data was obtained from the Metropolitan Transportation Authority (www.mta.info), Friends of the High Line (www.thehighline.org), and the New York City Department of Transportation Bike Parking maps (www.nyc.gov). Additional data was gathered from the Articles/Infographics "Visualizing Visitor Data" and "A Skyscraper on its Side," 2016.

Entrances were located every 2-3 blocks and correlate with bus, subway, and cross-street connections to Hudson River Park. Integrated signage on top of the High Line includes the street number below so that visitors are aware of their location within the city. Elevators are brightly colored and highly visible. The HL's logo and font is consistently applied to signage for recognizability.

Friends of the High Line was recognized in 2017 by the Mayor's Office for People with Disabilities with an ADA award for 'its unwavering commitment to upholding the Americans with Disabilities Act and the protections if provides under Title II, by ensuring its facilities and public programming are accessible to all park-goers. This organization is giving people with disabilities the opportunity to experience everything the High Line has to offer." 
6. EXPANDS USER EXPOSURE TO MULTI-CULTURAL CONTEMPORARY ART, EXHIBITING OVER 200 PIECES SINCE ITS OPENING IN 2009, REPRESENTING ARTISTS FROM 43 COUNTRIES, NORTH AMERICA - 97, MIDDLE EAST - 5, EUROPE - 66, CARIBBEAN - 1, ASIA - 9, AFRICA - 4, SOUTH AMERICA - 13, AND PACIFIC ISLANDS - 1.

Method:

Data extracted from Infographic in the article "A History of High Line Art", compiled by FHL. The following are the numbers of artists from each country from 2009-2016: Albania 1, Angola 1, Argentina 6, Austria 1, Belgium 1, Brazil 3, Canada 1, Chile 1, China 1, Colombia 2, Croatia 1, Cyprus 2, Denmark 5, Egypt 2, France 6, Georgia 2, Germany 6, Ghana 1, Iceland 1, Israel 4, Italy 11, Jamaica 1, Japan 5, Lebanon 1, Mexico 3, Netherlands 1, New Zealand 2, Norway 1, Poland 3, Portugal 2, Romania 1, Russia 1, Scotland 1, Serbia 1, Slovakia 1, South Korea 1, Spain 1, Sweden 3, Switzerland 5, United Kingdom 13, United States 89, Venezuela 1, and Vietnam 1.

\section{THE AVERAGE VISITOR TO THE HIGH LINE BURNS APPROXIMATELY 145 CALORIES PER VISIT.}

Method:

Per the FHL Visitor Study, the average visit to the HL is 37 minutes, with the top activity being walking. The following equation was used to estimate approximate calories burned per average user:

150lbs per person $\times 37$ minutes walking on a level surface $\times 1.5$ miles $=145$ calories 


\section{References:}

James Corner Field Operations, and Diller Scofidio + Renfro. The High Line: Seen Unforeseen, 2015. Phaidon Press Limited, 2015.

Egorov, Anton. "A Skyscaper on its Side". The High Line Magazine, 2016, 26 pp.

Field Operations, Applied Ecological Services, and Piet Oudolf. "The High Line, Phase 1 Ecological Assessment Report". Friends of the High Line. November 2, 2004.

Ganser, Adam. "Big Data \& Parks". The High Line Magazine, 2016, 26 pp.

Glenn, Steve. "Railyards Plant Survey". Friends of the High Line. 28 Sept 2011.

Hamilton, Rabinovitz \& Alschuler, Inc. (HR\&A). "The High Line: The Feasibility and Economic Impact of Re-Use". 26 Dec. 2002.

Kuijpers, Sonja. "A History of High Line Art". The High Line Magazine, 2016, 26 pp.

Ley, Elizabeth. "Selecting Plants for Pollinators: A Regional Guide for Farmers, Land Managers, and Gardeners in the Ecological Region of the Eastern Broadleaf Forest Oceanic Province Including the State of: Connecticut, New Jersey, Rhode Island and Parts of: Delaware, Kentucky, Maine, Maryland, Massachusetts, New Hampshire, New York, Ohio, Pennsylvania, Tennessee, West Virginia". NAPPC and Pollinator Partnership Publication. www.pollinator.org. Accessed 5 Aug. 2017.

Offwell Woodland \& Wildlife Trust. "Simpson's Diversity Index". <http://www.countrysideinfo.co.uk/simpsons.htm>. Accessed 9 Aug 2017.

Spargo, John, Tracy Allen, and Solomon Kariuki. Interpreting Your Soil Test Results. UMassAmherst: The Center for Agriculture, Food and the Environment, 1 July 2013. <http://ag.umass.edu/soil-plant-tissue-testinglab/fact-sheets/interpreting-your-soil-test-results>. Accessed 4 Aug. 2017.

Statler, Richard. The flora on the High Line, New York City, New York. Journal of the Torrey Botanical Society 131 (4), 2004, pp. 387-393.

Switkin, Lisa. Personal interview. July 28, 2017.

Zolotarsky, Masha. "Visualizing Visitor Data”. The High Line Magazine, 2016, 26 pp. 